Article

\title{
Nutritional Characteristics of Four Underutilized Edible Wild Fruits of Dietary Interest in Ghana
}

\author{
Matthew Atongbiik Achaglinkame ${ }^{1}\left(\mathbb{D}\right.$, Ruth Olaide Aderibigbe ${ }^{2}$, Oliver Hensel ${ }^{3}(\mathbb{D}$, \\ Barbara Sturm ${ }^{3}$ and Joseph Kudadam Korese ${ }^{1, *(D)}$ \\ 1 Faculty of Agriculture, Department of Agricultural Mechanization and Irrigation Technology, \\ University for Development Studies, P.O. Box TL 1882, Nyankpala Campus, Tamale, Ghana; \\ maachaglinkame@gmail.com \\ 2 Product Development Programme, National Horticultural Research Institute, Jericho G.R.A., \\ Ibadan 200272, Oyo State, Nigeria; connecttolaide@yahoo.com \\ 3 Faculty of Organic Agricultural Sciences, Section of Agricultural and Biosystems Engineering, \\ University of Kassel, Nordbahnhofstraße 1a., 37213 Witzenhausen, Germany; \\ agrartechnik@uni-kassel.de (O.H.); barbara.sturm@uni-kassel.de (B.S.) \\ * Correspondence: jkorese@uds.edu.gh; Tel.: +233-(0)-20-523-1357
}

Received: 10 February 2019; Accepted: 27 February 2019; Published: 20 March 2019

\begin{abstract}
Malnutrition has been a serious issue in Ghana and Africa as a whole. However, the potential of many indigenous fruits to combat it has not yet been tested. Therefore, this study aimed to determine the nutritional characteristics of four underutilized wild fruits (Gardenia erubescens, Sclerocarya birrea, Diospyros mespiliformis, and Balanites aegyptiaca) of dietary interest in Ghana. The nutritional and antinutritional characteristics of the fruits were analyzed according to standard methods (laid down by the Association of Official Analytical Chemists and other well-known researchers) on a dry weight $(\mathrm{dw})$ basis. The nutritional value of the fruits was high enough to contribute to the nutrient requirements of humans, with their iron $(0.34-1.46 \mathrm{mg} / 100 \mathrm{~g})$, zinc $(0.81-2.97 \mathrm{mg} / 100 \mathrm{~g})$, vitamin A $(0.84-2.03 \mathrm{mg} / 100 \mathrm{~g})$, and $\beta$-carotene (64.84-176.89 $\mathrm{mg} / 100 \mathrm{~g}$ ) contents worth special mention. The antinutrient content also ranged between $0.06-1.82 \mathrm{mg} / \mathrm{g}$. Therefore, it is evident from the study that the fruits, although containing some levels of antinutrients, are nutrient-dense, suggesting their potency in fighting malnutrition in humans.
\end{abstract}

Keywords: malnutrition; underutilized; wild forest fruits; nutritional value

\section{Introduction}

Underutilized edible wild fruits have become a very important part of human nutrition and cannot be overlooked as far as food security, good health, and income generation are concerned [1,2]. These wild fruits provide humans with very essential nutrients such as dietary fiber, protein, and sugars, as well as health-promoting phytochemicals and minerals [3]. Recent research has suggested that wild fruits have a curing ability for multiple disorders such as diabetes, cardiovascular problems, inflammations, and digestive and urinary tract disorders, among others, due to their rich fiber and antioxidant components [4-6]. Thus, food insecurity in developing countries can be reduced by motivating rural poor communities to increase their consumption of indigenous fruits as well as fruit-based food supplements. Accordingly, the Food and Agricultural Organization of the United Nations (FAO) is currently promoting the conservation and sustainable use of biodiversity for nutrition and agriculture as a means to increase dietary diversity [7-9]. However, the main problem relating to the full exploitation of some of these wild fruits is the presence of some antinutrients, which have the potential to reduce especially protein and starch digestibility and mineral bioavailability [10-12]. 
Many African countries including Ghana are greatly blessed with lots of fruit-bearing species, which yield both domesticated and wild fruits $[2,13,14]$ at one point or another throughout the year. However, it is disappointing that nutrient deficiencies are still very common and alarming especially among children and pregnant women in the country. Statistics shows that about $66 \%$ of children aged 6-59 months and $42 \%$ women of reproductive age (15-49 years) in Ghana are anemic $[15,16]$. Furthermore, about $75 \%$ of young children and $20 \%$ of pregnant women in Ghana are vitamin A-deficient [17].

Research by Bvenura and Sivakumar [2] showed that many people in sub-Saharan Africa do not eat enough fruits, and this compromises the delivery of a balanced and healthy diet. In Ghana for example, about $56 \%$ of adolescents rarely ( $\leq 3$ days per week) consumed fruits [18]. However, the World Health Organization (WHO) recommends a daily intake of more than $400 \mathrm{~g}$ of fruit per person to protect against diet-related non-communicable diseases [19]. Several factors have been opined to be the root causes of the low consumption, some of which include unavailability, unaffordability, ignorance, and neglect [20-22]. Ignorance and neglect may paramountly account for the low consumption of fruits in areas such as Ghana where nature generously supplies varieties of fruits all year round. Some foods are sometimes tagged as poor people's foods [23], and thus are deliberately ignored. Lack of knowledge of the nutritional and health benefits of certain foods makes some people, the educated and uneducated alike, disregard these foods [24,25]. This may not be different in the case of Ghana following statistical evidence of nutrient deficiencies, despite the availability of both domesticated and wild fruits in the various parts of the country. The consumption of predominantly traditional starchy crops (cereals and root crops), especially by the rural poor, is also reported to impose both micronutrient and protein malnutrition [26].

To recommend wild fruits as a contribution to an improved diet, knowledge about the nutritional value is required. A food composition database is of great importance in addressing health and nutrition issues. According to Stadlmayr et al. [27], such a database is important for planning food, nutrition, and health-related policy tools. As a result, there is a worldwide call to develop a National Food Composition Database. Moreso, nutritional information is required in order to develop processing guidelines for the production of target, processed products that are suitable for low-income populations. Unfortunately, Ghana does not have a national food database of its own.

Therefore, the current study was conducted to evaluate the nutritional characteristics of four (4) wild fruits, namely Gardenia erubescens, Sclerocarya birrea, Diospyros mespiliformis, and Balanites aegyptiaca from Ghana. Literature search has shown that the fruits of G. erubescens, S. birrea, D. mespiliformis, and B. aegyptiaca have been characterized through the fruit or pulp [28-30] and seeds [31,32] in some parts of the world. Studies have provided some promising nutritional information especially on the proximate, mineral compositions [28-30] and vitamin C content $[28,29]$ of one or more of these fruits. Bello et al. [29] have also reported the presence of some antinutrients such as tannin, phytate, and oxalate in G. erubescens and other fruits in their study. While these data are relevant, information on these Ghanaian wild fruits is lacking. Furthermore, the soil and climatic conditions of different regions result in a significant difference in the food composition of the food that is produced, and therefore data cannot simply be borrowed between countries. Besides, information on other vital nutrients such as vitamin $A, \beta$-carotene, and other phytochemicals such as polyphenols and flavonoids is limited if not lacking, hence this study. The data in this study may be incorporated into food nutrient databases such as the FAO/INFOODS (International Network of Food Data Systems) databases, and also foster renewed interest in their use in contemporary diets, especially in Ghana. 


\section{Materials and Methods}

\subsection{Source of Raw Materials}

Fruit samples (Table 1) were obtained from the wild in Wiaga $\left(10^{\circ} 39^{\prime} 0^{\prime \prime} \mathrm{N}, 1^{\circ} 16^{\prime} 0^{\prime \prime} \mathrm{W}\right)$, in the Builsa North District of the Upper East region of Ghana. The fruits were taken from as many different plants of each type as could be accessed in the fresh state, except for Diospyros mespiliformis, which were in the dried state at the time of collection, because the fresh ones were out of season. The fruits were transported to the laboratory and stored at $4{ }^{\circ} \mathrm{C}$ prior to processing.

Table 1. Names, pictures, and sampling dates of the fruit samples used for the study.

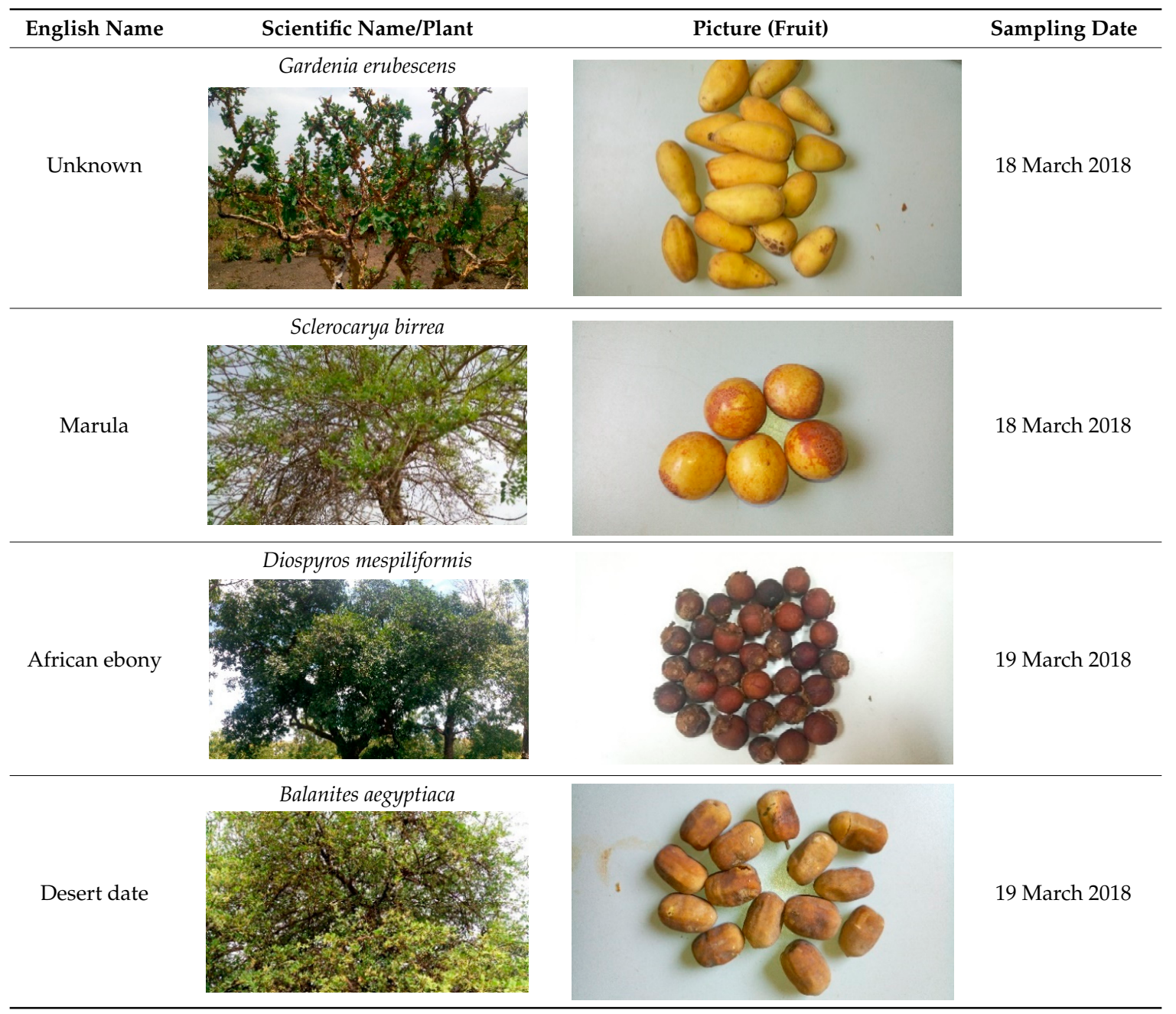

\subsection{Sample Preparation and Processing}

The fruits obtained were sorted and washed where applicable. Then, seeds and unwanted parts were removed manually with the aid of stainless steel knives, while only the edible portions of the fruit were used for the study. The pulp and peel of G. erubescens, S. birrea, and D. mespiliformis and pulp of B. aegyptiaca were the parts of the fruits that were used for the study. Then, the fruit samples were dried at $60^{\circ} \mathrm{C}$ for $12 \mathrm{~h}$ in a hot-air oven, according to Afolabi [33]. The dried samples were milled using a Moulinex miller (MC300, Moulinex, Hong Kong, China) and stored in airtight Ziploc bags at $4{ }^{\circ} \mathrm{C}$ until analysis. 


\subsection{Chemical Analysis}

\subsubsection{Proximate}

The moisture, ash, protein, fiber, and fat contents of the samples were analyzed according to Association of Official Analytical Chemists (AOAC) procedures [34]. Carbohydrate content was calculated as the difference: $100-($ moisture $(\mathrm{g})+$ protein $(\mathrm{g})+$ fiber $(\mathrm{g})+\mathrm{fat}(\mathrm{g})+\mathrm{ash}(\mathrm{g}))[34]$. All analyses were performed in triplicate. The results were expressed in g per $100 \mathrm{~g}$ of dry weight $(\mathrm{g} / 100 \mathrm{~g} \mathrm{dw})$. The energy content of each fruit was calculated as follows: Energy $(\mathrm{kcal} / 100 \mathrm{~g})=$ $4 \times$ protein $(\mathrm{g})+4 \times$ carbohydrates $(\mathrm{g})+9 \times$ fat $(\mathrm{g})$.

\subsubsection{Determination of $\mathrm{pH}$, Total Soluble Solids, and Titratable Acidity}

Ten grams of each milled sample were dissolved in $100 \mathrm{~mL}$ of distilled water. Then, the $\mathrm{pH}$ was determined using a pH meter BASIC 20 manufactured by Crison Instruments (Alella, Spain) after the solution was stirred for $30 \mathrm{~min}$ and left to rest for $10 \mathrm{~min}$. Total soluble solids (TSS) were determined using an Atago DR-A1digital refractometer (Atago Co. Ld., Tokyo, Japan) at $25^{\circ} \mathrm{C}$. Titratable acidity was determined on $10 \%$ slurry of each sample. The slurry was filtered, and $50 \mathrm{~mL}$ of the filtrate was transferred into a clean 250-mL beaker. Three drops of phenolphthalein indicator were added to the solution, and $0.1 \mathrm{M}$ of $\mathrm{NaOH}$ was slowly titrated to an endpoint. Then, titratable acidity was calculated as percent citric acid as follows: Acidity $(\%)=($ titre value $(\mathrm{mL} \mathrm{NaOH}) \times$ acid value $(0.0064) \times$ $100 \mathrm{~mL}) /($ Sample Weight $) \times 50 \mathrm{~mL}$.

\subsubsection{Mineral Determination}

The digestion of the samples was done by wet ashing, and the calcium (Ca), potassium (K), magnesium $(\mathrm{Mg})$, phosphorus $(\mathrm{P})$, sodium $(\mathrm{Na})$, iron $(\mathrm{Fe})$, and zinc $(\mathrm{Zn})$ contents of the fruits were quantified with a Flame Atomic Absorption Spectrophotometer (AAS Model Nov AA 400p) according to [34].

\subsection{Vitamins (A,B3, C), $\beta$-Carotene, Total Polyphenols, and Flavonoids}

The vitamin A, B3, and C contents and the $\beta$-carotene content of the fruits were also determined following the procedures of [34]. The polyphenol content was determined according to the method described by Singleton et al. [35]. One gram of dried powdered sample of each of the fruits was soaked in $10 \mathrm{~mL}$ of methanol $70 \%(w / v)$ and centrifuged at $1000 \mathrm{rpm}$ for $10 \mathrm{~min}$. Then, one milliliter of the supernatant was oxidized with $1 \mathrm{~mL}$ of Folin-Ciocalteu's reagent and neutralized by $1 \mathrm{~mL}$ of $20 \%(w / v)$ sodium carbonate afterwards. After incubating the reaction mixture for $30 \mathrm{~min}$ at ambient temperature, absorbance was measured at $745 \mathrm{~nm}$ using a spectrophotometer (PG Instruments, England). A calibration curve of gallic acid $(1 \mathrm{mg} / \mathrm{mL})$ as standard was used to obtain the polyphenol content. Each analysis was repeated thrice, and the average value was obtained. The same procedure was followed for the preparation of the standard solution of gallic acid. The total flavonoid content was determined according the method ascribed by Meda et al. [36]. Briefly, $0.5 \mathrm{~mL}$ of the methanolic extract was mixed with $0.5 \mathrm{~mL}$ of methanol, $0.5 \mathrm{~mL}$ of $\mathrm{AlCl} 3(10 \%, w / v), 0.5 \mathrm{~mL}$ of potassium acetate $(1 \mathrm{M})$, and $2 \mathrm{~mL}$ of distilled water. The mixture was allowed to incubate at ambient temperature for $30 \mathrm{~min}$. Thereafter, the absorbance was measured at $415 \mathrm{~nm}$ by using a spectrophotometer (PG Instruments, Woodway lane, UK). The total flavonoids were determined using a calibration curve of quercetin $(0.1 \mathrm{mg} / \mathrm{mL})$ as standard. This procedure was repeated three times for each sample, and their mean values were computed. The same procedure was followed for the preparation of the standard solution of quercetin. 


\subsection{Antinutrient Determinations}

Phytate content was determined using the Wade's reagent colorimetric method [37]. One gram of the dried powdered sample was mixed with $20 \mathrm{~mL}$ of hydrochloric acid $(0.65 \mathrm{~N})$ and stirred for $12 \mathrm{~h}$ with a magnetic stirrer. The mixture was centrifuged at 12,000 rpm for $40 \mathrm{~min}$. About $0.5 \mathrm{~mL}$ of supernatant was added to $3 \mathrm{~mL}$ of Wade's reagent. After the reaction mixture was incubated for $15 \mathrm{~min}$, absorbance was then taken at $490 \mathrm{~nm}$ with a spectrophotometer (PG Instruments). Phytate content was obtained using a calibration curve of sodium phytate $(10 \mathrm{mg} / \mathrm{mL})$ as standard. Oxalate content was determined using the titration method as outlined by Day and Underwood [38]. Tannin content was analyzed according to procedures established by Price et al. [39], while saponin content was determined according to Obadoni and Ochuko [40].

\subsection{Statistical Analysis}

The data obtained from the study were analyzed by one-way analysis of variance (ANOVA) followed by Tukey's studentized range test with significance set at $p \leq 0.05$ in the Minitab ${ }^{\circledR} 16.2 .2$ (Minitab Inc., State College, PA, USA) statistical tool, and the results are presented in scientific tables.

\section{Results and Discussion}

\subsection{Proximate and Physicochemical Properties}

The proximate and physicochemical properties of the four fruits are shown in Table 2 . The highest moisture content was recorded in S. birrea $(85.84 \%)$ while the least was recorded in D. mespiliformis $(6 \%)$. The reverse was the case for dry matter; D. mespiliformis had the highest $(93.99 \%)$, while $S$. birrea had the lowest (14.16\%). These observations are comparable to those in the literature $[29,41,42]$. The relatively higher moisture contents in S. birrea and G. erubescens suggest shorter storability if left unprocessed within a reasonable period of time, hence a need for processing into more stable products. Considering the relatively high dry matter contents of the fruits, it may be economically feasible for food product development, since too much raw material may not be needed to give a quantifiable amount of total solids.

Table 2. Proximate and physicochemical properties of four underutilized forest fruits.

\begin{tabular}{ccccc}
\hline \multirow{2}{*}{ Property } & \multicolumn{4}{c}{ Fruit Samples } \\
\cline { 2 - 5 } & G. erubescens & S. birrea & D. mespiliformis & B. aegyptiaca \\
\hline Moisture (\%) & $70.43 \pm 0.24^{\mathrm{a}}$ & $85.84 \pm 0.14^{\mathrm{b}}$ & $6.01 \pm 0.00^{\#}$ & $18.27 \pm 0.10^{\mathrm{c}}$ \\
Dry matter (\%) $^{*}$ & $29.57 \pm 0.21^{\mathrm{a}}$ & $14.16 \pm 0.38^{\mathrm{b}}$ & $93.99 \pm 0.02^{\#}$ & $81.73 \pm 0.92^{\mathrm{c}}$ \\
Carbohydrate (\%) & $76.44 \pm 0.51^{\mathrm{a}}$ & $61.69 \pm 0.69^{\mathrm{b}}$ & $75.23 \pm 0.40^{\mathrm{a}}$ & $73.63 \pm 0.38^{\mathrm{c}}$ \\
Protein (\%) & $8.83 \pm 0.09^{\mathrm{a}}$ & $12.48 \pm 0.02^{\mathrm{b}}$ & $10.26 \pm 0.01^{\mathrm{c}}$ & $9.19 \pm 0.05^{\mathrm{d}}$ \\
Ash (\%) & $3.4 \pm 0.20^{\mathrm{a}}$ & $6.37 \pm 0.25^{\mathrm{b}}$ & $3.00 \pm 0.20^{\mathrm{a}}$ & $4.4 \pm 0.20^{\mathrm{c}}$ \\
Fat (\%) & $4.53 \pm 0.22^{\mathrm{a}}$ & $9.68 \pm 0.17^{\mathrm{b}}$ & $3.51 \pm 0.18^{\mathrm{c}}$ & $2.58 \pm 0.37^{\mathrm{d}}$ \\
Fiber (\%) & $2.27 \pm 0.14^{\mathrm{a}}$ & $4.25 \pm 0.17^{\mathrm{b}}$ & $2.00 \pm 0.13^{\mathrm{a}}$ & $2.93 \pm 0.14^{\mathrm{c}}$ \\
Energy (kcal) & $381.85 \pm 1.61^{\mathrm{a}}$ & $383.81 \pm 2.24^{\mathrm{a}}$ & $373.55 \pm 1.00^{\mathrm{b}}$ & $354.48 \pm 1.93^{\mathrm{c}}$ \\
pH & $4.64 \pm 0.05^{\mathrm{a}}$ & $4.20 \pm 0.02^{\mathrm{b}}$ & $5.44 \pm 0.04^{\mathrm{c}}$ & $5.35 \pm 0.03^{\mathrm{c}}$ \\
TSS ( ${ }^{\circ}$ Brix) & $1.01 \pm 0.43^{\mathrm{a}}$ & $1.21 \pm 0.33^{\mathrm{a}}$ & $1.56 \pm 0.15^{\mathrm{a}}$ & $1.27 \pm 0.61^{\mathrm{a}}$ \\
TA (\% citric acid) & $1.04 \pm 0.07^{\mathrm{a}}$ & $1.98 \pm 0.31^{\mathrm{b}}$ & $2.04 \pm 0.03^{\mathrm{b}}$ & $2.35 \pm 0.47^{\mathrm{b}}$ \\
\hline
\end{tabular}

Values are mean \pm standard deviation. Values with different superscripts in the same row are significantly statistically different. * Determined per $100 \mathrm{~g}$ of fresh weight of sample except for $D$. mespiliformis, while the rest were determined per $100 \mathrm{~g}$ dry weight of the sample. \# Sample was in the dried state at the time of collection; hence, it was statistically inappropriate to compare its moisture and dry matter with those of the fresh ones. TSS: total soluble solids, TA: titratable acids. 
The carbohydrate content averagely varied from $61.69 \%$ in S. birrea to $76.44 \%$ in G. erubescens, representing about $27-59 \%$ of the recommended dietary allowance (RDA) of carbohydrate (130-210 g/day) across all age groups [43]. This means that the fruits have a great potential to supply the human body with good amounts of its primary source of energy. Generally, high protein values were recorded among the fruits, with S. birrea having the highest values $(12.48 \%)$, while G. erubescens had the lowest $(8.83 \%)$. The protein value of $S$. birrea in this study is quite higher than that $(8 \%)$ cited by Mateke [44]; likewise, that of B. aegyptiaca $(9.19 \%)$ was also higher than that (6.39\%) cited by Mateke, as reported by Admassu, Bekele, and Kim [28]. With these inherent protein values, these fruits may be able to contribute about $16-123 \%$ to the daily protein requirement, depending on the age group.

The ash content of the fruits, which ranged from $3.00 \%$ in D. mespiliformis to $6.37 \%$ in S. birrea, is suggestive of their mineral power, and thus when consumed could play a significant role in curbing some micronutrient deficiencies troubling human lives. The ash value obtained for $S$. birrea was greater than the $4.9 \%$ reported by Amarteifio and Mosase [41], but similar to the $6.8 \%$ reported by Murray et al. [42]. However, the $4.4 \%$ recorded in this study for B. aegyptiaca is lower than the $5.66 \%$ reported by Admassu et al. [28].

The fat contents were averagely low except for S. birrea, whose value was relatively higher $(9.68 \%)$. Low fat values could mean that the fruits may play an important role in curtailing cardiovascular problems. Nevertheless, the relatively high fat content of S. birrea may provide a feeling of satiety, and thus could help reduce hunger. A range of $2.00 \%$ in D. mespiliformis to $4.25 \%$ in S. birrea was recorded as crude fiber for the fruits, which represents about 5-22\% of the RDA of fiber (19-38 g/day) for humans. This amount of fiber could be of immense importance in the digestive process of humans in controlling constipation. The energy content $(\mathrm{kcal})$ of the fruits was observed to increase with their fat contents, ranging from 354.48 in B. aegyptiaca to 383.81 in S. birrea. This suggests the fruits could supply approximately $11-19 \%$ of the energy (2071-3152 kcal/day) requirement of the body when consumed.

The $\mathrm{pH}$ values ranged from 4.20 in S. birrea to 5.44 in D. mespiliformis, indicating that the fruits are slightly acidic. However, the total soluble solid content of the fruits was low following a range of $1.01 \%$ in G. erubescens to $1.56 \%$ in D. mespiliformis. The titratable portions of the acid content of the fruits also varied from $1.04 \%$ in G. erubescens to $2.35 \%$ in B. aegyptiaca. The range for the titratable acidity in this study was similar to the $0.6-1.7 \%$ reported in $S$. birrea and other fruits elsewhere [31].

\subsection{Mineral Composition}

Generally, it could be observed that the fruits have relatively high concentrations of the minerals analyzed (Table 3). The concentration of calcium ranged from $6.48 \mathrm{mg} / 100 \mathrm{~g}$ in G. erubescens to $14.95 \mathrm{mg} / 100 \mathrm{~g}$ in S. birrea. Calcium plays an important role in strong bone and teeth formation, the regulation of muscle contractions, and the transmission of nerve impulses in the body; thus, its presence in human diets is a necessity [45].

Table 3. Mineral composition (mg/100 g dry weight, or $\mathrm{dw}$ ) of four edible underutilized forest fruits.

\begin{tabular}{ccccc}
\hline \multirow{2}{*}{ Mineral } & \multicolumn{4}{c}{ Fruit Samples } \\
\cline { 2 - 5 } & G. erubescens & S. birrea & D. mespiliformis & B. aegyptiaca \\
\hline Calcium & $6.48 \pm 0.04^{\mathrm{a}}$ & $14.95 \pm 0.17^{\mathrm{b}}$ & $8.81 \pm 0.28^{\mathrm{c}}$ & $10.58 \pm 0.11^{\mathrm{d}}$ \\
Potassium & $133.41 \pm 2.37^{\mathrm{a}}$ & $133.02 \pm 2.23^{\mathrm{a}}$ & $129.4 \pm 1.62^{\mathrm{a}}$ & $131.60 \pm 2.69^{\mathrm{a}}$ \\
Phosphorus & $46.37 \pm 0.91^{\mathrm{a}}$ & $103.87 \pm 4.32^{\mathrm{b}}$ & $64.78 \pm 2.98^{\mathrm{c}}$ & $55.23 \pm 0.23^{\mathrm{d}}$ \\
Magnesium & $168.07 \pm 0.44^{\mathrm{a}}$ & $177.69 \pm 0.43^{\mathrm{b}}$ & $162.98 \pm 0.42^{\mathrm{c}}$ & $166.81 \pm 0.51^{\mathrm{d}}$ \\
Sodium & $2.64 \pm 0.04^{\mathrm{a}}$ & $1.75 \pm 0.04^{\mathrm{b}}$ & $1.25 \pm 0.03^{\mathrm{c}}$ & $1.43 \pm 0.05^{\mathrm{d}}$ \\
Iron & $0.48 \pm 0.08^{\mathrm{a}}$ & $0.43 \pm 0.02^{\mathrm{ab}}$ & $1.46 \pm 0.03^{\mathrm{c}}$ & $0.34 \pm 0.01^{\mathrm{b}}$ \\
Zinc & $0.81 \pm 0.02^{\mathrm{a}}$ & $2.97 \pm 0.03^{\mathrm{b}}$ & $1.70 \pm 0.03^{\mathrm{c}}$ & $2.02 \pm 0.03^{\mathrm{d}}$ \\
\hline
\end{tabular}

Values are mean \pm standard deviation of three replicates. Values in the same row with different superscripts are statistically significantly different. 
Potassium concentration averagely ranged from $129.4 \mathrm{mg} / 100 \mathrm{~g}$ in D. mespiliformis to $133.41 \mathrm{mg} / 100 \mathrm{~g}$ in G. erubescens. However, there was no statistically noticeable variation in potassium concentration among the fruits $(p>0.05)$. Potassium plays a very crucial role in the body by helping maintain body fluid and osmotic balance, as well as aiding in the regulation of nerve signals and muscle contractions $[46,47]$. Phosphorus values, on the other hand, ranged significantly $(p<0.05)$ from $46.37 \mathrm{mg} / 100 \mathrm{~g}$ in G. erubescens to $103.87 \mathrm{mg} / 100 \mathrm{~g}$ in S. birrea. The role of phosphorus in the formation of strong bones and teeth, the maintenance of a regular heartbeat, muscle contraction, regulation of the storage and use of body energy, among other roles, cannot be undervalued.

A range of $162.98 \mathrm{mg} / 100 \mathrm{~g}$ in D. mespiliformis to $177.69 \mathrm{mg} / 100 \mathrm{~g}$ in $S$. birrea of magnesium was observed among the fruits, with each varying significantly $(p<0.05)$ from the other. It has been established that magnesium helps relax muscles along the respiratory pathway, enabling asthmatics to breathe with ease [29]. Its role in most phosphate transfer reactions, the structural stability of nucleic acid, and the intestinal absorption of nutrients also cannot be underestimated. Its deficiency has been linked with problems such as hypertension, stroke, severe diarrhea, and migraines, to mention a few [48]; however, the consumption of these fruits may help prevent these health issues, following their high values.

For sodium content, G. erubescens recorded the highest value $(2.64 \mathrm{mg} / 100 \mathrm{~g})$, while $D$. mespiliformis recorded the lowest $(1.25 \mathrm{mg} / 100 \mathrm{~g})$. Sodium is very crucial for the maintenance of fluid balance in the body. Iron and zinc also varied significantly from $0.34 \mathrm{mg} / 100 \mathrm{~g}$ in B. aegyptiaca to $1.46 \mathrm{mg} / 100 \mathrm{~g}$ in D. mespiliformis, and from $0.81 \mathrm{mg} / 100 \mathrm{~g}$ in G. erubescens to $2.97 \mathrm{mg} / 100 \mathrm{~g}$ in S. birrea, respectively. While iron is very vital for the transport of oxygen in the bloodstream and the control of anemia and its attendant effects, zinc is substantially linked with protein synthesis, the catalytic activity of several enzymes, and rapid growth and development during infancy, adolescence, and wound healing [29].

\subsection{Vitamins and Antioxidant Composition}

The vitamin and antioxidant contents of the fruits have been tabulated below (Table 4). The vitamin B3 (niacin) content of the fruits ranged significantly from $146.30 \mathrm{mg} / 100 \mathrm{~g}$ in G. erubescens to $932.74 \mathrm{mg} / 100 \mathrm{~g}$ in $S$. birrea. The role of niacin in cellular metabolism and cell longevity cannot be underestimated; thus, niacin plays a critical role in aging [49]. Vitamin C content (mg/100 g) varied significantly from $44.67 \mathrm{mg} / 100 \mathrm{~g}$ in D. mespiliformis to $172.49 \mathrm{mg} / 100 \mathrm{~g}$ in S. birrea. This vitamin is a crucial antioxidant that enhances non-heme iron transport and absorption, the reduction of folic acid intermediates, and the production of cortisol. Vitamin C is vital in the synthesis of collagen and other connective tissues. Its insufficiency in the body results in the fragility of blood capillaries, gum decay, and scurvy $[50,51]$.

Table 4. Vitamin and antioxidant compositions (mg/100 g) of four underutilized forest fruits.

\begin{tabular}{ccccc}
\hline \multirow{2}{*}{ Nutrient } & \multicolumn{4}{c}{ Fruit Samples } \\
\cline { 2 - 4 } & G. erubescens & S. birrea & D. mespiliformis & B. aegyptiaca \\
\hline Vitamin B3 & $146.30 \pm 1.48^{\mathrm{a}}$ & $932.74 \pm 7.24^{\mathrm{b}}$ & $310.22 \pm 8.15^{\mathrm{c}}$ & $227.85 \pm 3.80^{\mathrm{d}}$ \\
Vitamin C & $73.08 \pm 2.23^{\mathrm{a}}$ & $172.49 \pm 6.01^{\mathrm{b}}$ & $44.67 \pm 3.06^{\mathrm{c}}$ & $105.97 \pm 2.57^{\mathrm{d}}$ \\
Vitamin A & $1.17 \pm 0.24^{\mathrm{a}}$ & $2.03 \pm 0.03^{\mathrm{b}}$ & $1.57 \pm 0.32^{\mathrm{ab}}$ & $0.84 \pm 0.03^{\mathrm{ac}}$ \\
$\beta_{\text {B-carotene }}$ & $111.01 \pm 0.43^{\mathrm{a}}$ & $176.89 \pm 9.89^{\mathrm{b}}$ & $89.16 \pm 0.77^{\mathrm{c}}$ & $64.84 \pm 2.47^{\mathrm{d}}$ \\
Polyphenol (GAE) & $82.28 \pm 8.33^{\mathrm{a}}$ & $111.06 \pm 0.10^{\mathrm{b}}$ & $53.39 \pm 1.70^{\mathrm{c}}$ & $110.44 \pm 1.11^{\mathrm{b}}$ \\
Flavonoid (QE) & $172.67 \pm 8.08^{\mathrm{a}}$ & $237.67 \pm 13.50^{\mathrm{b}}$ & $94.00 \pm 4.00^{\mathrm{c}}$ & $160.00 \pm 6.00^{\mathrm{a}}$ \\
\hline
\end{tabular}

Values are mean \pm standard deviation of three replicates. Values in the same row with different superscripts are statistically significantly different. GAE-Gallic acid equivalents; QE-Quercetin equivalents. 
Vitamin A is another vital nutrient that is known for its significant role in normal vision, gene expression, growth, and immune functioning [52]. Its content ranged from $0.84 \mathrm{mg} / 100 \mathrm{~g}$ in B. aegyptiaca to $2.03 \mathrm{mg} / 100 \mathrm{~g}$ in S. birrea. For $\beta$-carotene (pro-vitamin A) content, the highest $(176.89 \mathrm{mg} / 100 \mathrm{~g})$ was recorded in S. birrea and the lowest $(64.84 \mathrm{mg} / 100 \mathrm{~g})$ was recorded in B. aegyptiaca. Beta-carotene enhances the growth of cells and tissues, fortifies the immune system against diseases, and delays aging. Besides that, it helps keep the eye, skin, nails, and hair functioning effectively [53]. The $\beta$-carotene values of the fruits serve as a great backup to their vitamin A levels, and therefore could be converted to vitamin $\mathrm{A}$ in the body to supplement it.

Polyphenols are known for their free radical scavenging and anticancer properties due to their antioxidant activity [54]. Polyphenol content ranged from $53.39 \mathrm{mg} / 100 \mathrm{~g}$ in D. mespiliformis to $111.06 \mathrm{mg} / 100 \mathrm{~g}$ in $S$. birrea, showing the strong potentials of the fruits to arrest free radicals that cause health problems in the body. Flavonoids, another type of antioxidant, possess a strong anti-inflammatory effect, and also protect the body cells against free radical damage, thereby helping control cardiovascular and cancerous problems [55]. Therefore, a range of $94.00 \mathrm{mg} / 100 \mathrm{~g}$ in D. mespiliformis to $237.67 \mathrm{mg} / 100 \mathrm{~g}$ in $S$. birrea could be a strong source of fortification against free radical effects.

\subsection{Antinutrient Composition}

The antinutrients (phytate, oxalate, tannin, and saponin) that were reported generally differed significantly $(p<0.05)$ among the fruits (Table 5$)$. The phytate content $(\mathrm{mg} / \mathrm{g})$ varied from $0.06 \mathrm{mg} / \mathrm{g}$ in G. erubescens to $1.82 \mathrm{mg} / \mathrm{g}$ in B. aegyptiaca. Phytate impedes the absorption of phosphorus, calcium, magnesium, iron, and zinc by forming complexes with them, and reduces amino acid digestibility. This makes these minerals readily unavailable to the body [29]. However, the phytate values obtained in this study were lower than the $10-60 \mathrm{mg} / \mathrm{g}$ that has been reported to pose mineral bioavailability problems [56]. The values in this study also averagely fall within the range of $0.37-0.90 \mathrm{mg} / \mathrm{g}$ of fruits (guava, mango, orange, and pineapple) that has been recommended elsewhere for diabetics [57]. Despite causing mineral bioavailability problems, phytate is an antioxidant and an anticancer agent.

Table 5. Antinutrient content $(\mathrm{mg} / \mathrm{g}$ ) of four underutilized forest fruits.

\begin{tabular}{ccccc}
\hline \multirow{2}{*}{ Fruit } & \multicolumn{4}{c}{ Antinutrient } \\
\cline { 2 - 5 } & Phytate & Oxalate & Tannin & Saponin \\
\hline Gardenia erubescens & $0.06 \pm 0.02^{\mathrm{a}}$ & $0.25 \pm 0.02^{\mathrm{a}}$ & $0.29 \pm 0.09^{\mathrm{a}}$ & $0.72 \pm 0.08^{\mathrm{a}}$ \\
Sclerocarya birrea & $0.64 \pm 0.04^{\mathrm{b}}$ & $0.11 \pm 0.00^{\mathrm{b}}$ & $0.59 \pm 0.08^{\mathrm{b}}$ & $1.05 \pm 0.06^{\mathrm{b}}$ \\
Diospyros mespiliformis & $0.27 \pm 0.02^{\mathrm{c}}$ & $0.14 \pm 0.00^{\mathrm{c}}$ & $0.46 \pm 0.13^{\mathrm{b}}$ & $0.22 \pm 0.01^{\mathrm{c}}$ \\
Balanites aegyptiaca & $1.82 \pm 0.09^{\mathrm{d}}$ & $0.38 \pm 0.00^{\mathrm{d}}$ & $0.40 \pm 0.03^{\mathrm{ab}}$ & $0.62 \pm 0.06^{\mathrm{a}}$ \\
\hline
\end{tabular}

Values are mean \pm standard deviation of three replicates. Values in the same row with different superscripts are statistically significantly different.

Oxalate values varied from $0.11 \mathrm{mg} / \mathrm{g}$ in $S$. birrea to $0.38 \mathrm{mg} / \mathrm{g}$ in B. aegyptiaca. Oxalate is known to inhibit renal calcium absorption, especially at concentrations of about $45 \mathrm{~g} / 100 \mathrm{~g}$ [58]. However, the values obtained in this study are far less than the value that is postulated to be harmful. This suggests that the fruits may not pose any mineral absorption problems if consumed. Tannin content ranged between $0.29 \mathrm{mg} / \mathrm{g}$ in G. erubescens to $0.59 \mathrm{mg} / \mathrm{g}$ in S. birrea, which is lower than the 1.01 to $7.5 \mathrm{mg} / \mathrm{g}$ reported by [31] for similar forest fruits. Tannin has been shown to reduce the palatability of foods with its astringency, inhibit enzyme activities, and reduce protein solubility and digestibility by complexing with them [31]. However, the low tannin content of these fruits may not pose any serious health problems. Saponin content was lowest in D. mespiliformis $(0.22 \mathrm{mg} / \mathrm{g})$, but highest in $S$. birrea $(1.05 \mathrm{mg} / \mathrm{g})$. Saponins foam in aqueous solution, and have a characteristic bitter taste that may be imparted to food if it is present in large amounts [59]. Saponins cause the rupturing of red blood cells and trigger nausea and vomiting; nevertheless, they beneficially reduce 
hypocholesterolemic problems in humans [60]. Research has shown that $\beta$-carotene and vitamins $\mathrm{A}$ and $C$ are good enhancers of the absorption of minerals such as iron and zinc [61]. Thus, with high contents of $\beta$-carotene, and vitamins $A$ and $C$, antinutrient activity can be inhibited to enhance mineral absorption in the body.

\section{Conclusions}

The study revealed that Gardenia erubescens, Sclerocarya birrea, Diospyros mespiliformis, and Balanites aegyptiaca are nutritionally sound following their recommendable proximate, mineral, and vitamin/antioxidant values, and contribution to the daily nutrient requirements in humans. The antinutrient contents of the fruits were relatively low, and might not pose any serious health problems, especially with their high concentration of mineral absorption enhancers such as $\beta$-carotene and vitamins $A$ and $C$. Therefore, with the nutritional and antinutritional information provided in this study, it is evident that these forest fruits, which lack public patronage and consumption in the Ghanaian community despite their availability, could be relied on to fight hunger and some nutrient deficiencies. However, due to the seasonality and perishability of the fruits, it would be very expedient to process them into finished and novel food products such as beverages, bakeries, or cookies to ensure extended consumption.

Author Contributions: Conceptualization, M.A.A. and J.K.K.; Funding acquisition, O.H., B.S. and J.K.K.; Investigation, M.A.A. and R.O.A.; Writing—original draft, M.A.A. and J.K.K.; Writing-review and editing, R.O.A., O.H., B.S.

Funding: This study is part of an ongoing project, UPGRADE Plus (323-06.01-03-2816PROC01), which is financially supported by the German Federal Ministry of Food and Agriculture based on the decision of the Parliament of the Federal Republic of Germany through the Federal Office for Agriculture and Food.

Acknowledgments: The authors gratefully acknowledge financial support from the funding body.

Conflicts of Interest: The authors declare that there is no conflict of interest.

\section{References}

1. Aworh, O.C. Promoting food security and enhancing Nigeria's small farmers' income through value-added processing of lesser-known and under-utilized indigenous fruits and vegetables. Food Res. Int. 2015, 76, 986-991. [CrossRef]

2. Bvenura, C.; Sivakumar, D. The role of wild fruits and vegetables in delivering a balanced and healthy diet. Food Res. Int. 2017, 99, 15-30. [CrossRef] [PubMed]

3. Kubola, J.; Siriamornpun, S.; Meeso, N. Phytochemicals, vitamin C and sugar content of Thai wild fruits. Food Chem. 2011, 126, 972-981. [CrossRef]

4. Alissa, E.M.; Ferns, G.A. Dietary fruits and vegetables and cardiovascular diseases risk. Crit. Rev. Food Sci. Nutr. 2017, 57, 1950-1962. [CrossRef] [PubMed]

5. Egea, I.; Sánchez-bel, P.; Romojaro, F. Six edible wild fruits as potential antioxidant additives or nutritional supplements. Plant. Foods Hum. Nutr. 2010, 65, 121-129. [CrossRef] [PubMed]

6. Shaheen, S.; Ahmad, M.; Haroon, N. Nutritional contents and analysis of edible wild plants. In Edible Wild Plants: An Alternative Approach to Food Security; Springer: Basel, Switzerland, 2017; pp. 127-133.

7. Bach-Faig, A.; Berry, E.M.; Lairon, D.; Reguant, J.; Trichopoulou, A.; Dernini, S.; Medina, F.X.; Battino, M.; Belahsen, R.; Miranda, G.; et al. Mediterranean diet pyramid today. Science and cultural updates. Public Health Nutr. 2011, 14, 2274-2284. [CrossRef]

8. Burlingame, B.; Charrondiere, U.R.; Dernini, S.; Stadlmayr, B.; Mondovì, S. Food biodiversity and sustainable diets: Implications of applications for food production and processing. In Green Technologies in Food Production and Processing; Boye, J., Arcand, Y., Eds.; Springer: Boston, MA, USA, 2012; pp. 643-657.

9. Charrondière, U.R.; Stadlmayr, B.; Rittenschober, D.; Mouille, B.; Nilsson, E.; Medhammar, E.; Olango, T.; Eisenwagen, S.; Persijn, D.; Ebanks, K.; et al. Food Chemistry FAO/INFOODS food composition database for biodiversity. Food Chem. 2013, 140, 408-412. [CrossRef] 
10. Dah-nouvlessounon, D.; Adjanohoun, A.; Sina, H.; Noumavo, P.A.; Diarrasouba, N.; Parkouda, C.; Madodé, Y.E.; Dicko, M.H.; Baba-Moussa, L. Nutritional and anti-nutrient composition of three kola nuts (Cola nitida, Cola acuminata and Garcinia kola) produced in Benin. Food Nutr. Sci. 2015, 6, 1395-1407. [CrossRef]

11. Elinge, C.M.; Muhammad, A.; Atiku, F.A.; Itodo, A.U.; Peni, I.J.; Sanni, O.M.; Mbongo, A.N. Proximate, mineral and anti-nutrient composition of pumpkin (Cucurbita pepo L.) seeds extract. Int. J. Plant. Res. 2012, 2, 146-150. [CrossRef]

12. Hassan, L.G.; Dangoggo, S.M.; Hassan, S.W.; Muhammad, S.; Umar, K.J. Nutritional and antinutritional composition of Sclerocarya birrea fruit juice. Nigerian J. Basic Appl. Sci. 2010, 18, 222-228. [CrossRef]

13. Boateng, S.K.; Yeboah, E.A.; Amponsah, J.Y. Wet season collection of edible wild fruits in three Regions of Ghana. J. Plant. Sci. 2007, 2, 353-357. [CrossRef]

14. Bvenura, C.; Afolayan, A.J. The role of wild vegetables in household food security in South Africa: A review. Food Res. Int. 2015, 76, 1001-1011. [CrossRef]

15. Ghana Statistical Service (GSS); Ghana Health Service (GHS); ICF International. Ghana Demographic and Health Survey 2014. GSS, GHS, ICF International, 2015. Available online: https:/ / dhsprogram.com/pubs/ pdf/fr307/fr307.pdf (accessed on 9 July 2018).

16. Ghana Health Service. Ghana: Landscape Analysis of Anemia and Anemia Programming; SPRING: Arlington, VA, USA, 2016; pp. 1-64.

17. World Health Organization. Global Prevalence of Vitamin a Deficiency in Populations at Risk 1995-2005: WHO Global Database on Vitamin a Deficiency; WHO Press: Geneva, Switzerland, 2009.

18. Doku, D.; Koivusilta, L.; Raisamo, S.; Rimpelä, A. Socio-economic differences in adolescents' breakfast eating, fruit and vegetable consumption and physical activity in Ghana. Public Health Nutr. 2013, 16, 864-872. [CrossRef]

19. World Health Organization. Diet. Nutrition and the Prevention of Chronic Diseases; World Health Organization: Geneva, Switzerland, 2003; pp. 1-160.

20. Miller, V.; Yusuf, S.; Chow, C.K.; Dehghan, M.; Corsi, D.J.; Lock, K.; Popkin, B.; Rangarajan, S.; Khatib, R.; Lear, S.A.; et al. Availability, affordability, and consumption of fruits and vegetables in 18 countries across income levels: Findings from the Prospective Urban Rural Epidemiology (PURE) study. Lancet Glob. Health 2016, 4, e695-e703. [CrossRef]

21. Reicks, M.; Randall, J.L.; Haynes, B.J. Factors affecting consumption of fruits and vegetables by low income families. J. Am. Diet. Assoc. 1994, 94, 1309-1311. [CrossRef]

22. Valmórbida, J.L.; Vitolo, M.R. Factors associated with low consumption of fruits and vegetables by preschoolers of low socio-economic level. J. Pediatr. 2014, 90, 464-471. [CrossRef]

23. Woolfe, J.A. The contribution of sweetpotato and its products to human diets. In Sweetpotato Technology for the 21st Century; Hill, W.A., Bonsi, C.K., Loretan, P.A., Eds.; Tuskegee University: Tuskegee, AL, USA, 1992; pp. 367-380.

24. Nti, C.A.; Hagan, J.; Bagina, F.; Seglah, M. Knowledge of nutrition and health benefits and frequency of consumption of fruits and vegetables among Ghanaian homemakers. Afr. J. Food Sci. 2011, 5, 333-339.

25. Omari, R.; Quorantsen, K.; Omari, P. Nutrition knowledge and food consumption practices and barriers in rural Ghana: The case of foods for preventing vitamin a and iron deficiencies. Afr. J. Food Agric. Nutr. Dev. 2017, 17, 11639-11656. [CrossRef]

26. Afari-Sefa, V.; Tenkouano, A.; Ojiewo, C.O.; Keatinge, J.D.H.; Hughes, J.D.A. Vegetable breeding in Africa: Constraints, complexity and contributions toward achieving food and nutritional security. Food Secur. 2012, 4, 115-127. [CrossRef]

27. Stadlmayr, B.; Charrondière, U.R.; Burlingame, B. Development of a regional food composition table for West Africa. Food Chem. 2013, 140, 443-446. [CrossRef]

28. Admassu, M.; Bekele, A.; Kim, J.C. Nutritional Composition of Balanites aegyptiaca (Desert Date) and Hyphaene thebaica (Doum Palm) Fruits Consumed by Hamadryas Baboons (Papio hamadryas hamadryas) in Awash National Park, Ethiopia. J. Nutr. Ecol. Food Res. 2013, 1, 198-206. [CrossRef]

29. Bello, M.O.; Falade, O.S.; Adewusi, S.R.A.; Olawore, N.O. Studies on the chemical compositions and anti nutrients of some lesser known Nigeria fruits. Afr. J. Biotech. 2008, 7, 3972-3979.

30. Magaia, T.; Uamusse, A.; Sjöholm, I.; Skog, K. Proximate analysis of five wild fruits of mozambique. Sci. World J. 2013, 2013, 1-7. [CrossRef] 
31. Magaia, T. Chemical Analysis to promote the use of wild fruits from Mozambique Lund University. Ph.D. Thesis, Lund University, Lund, Sweden, September 2015.

32. Zang, C.U.; Jock, A.A.; Garba, I.H.; Chindo, I.Y. Physicochemical and Phytochemical Characterization of Seed Kernel oil From Desert Date (Balanites Aegyptiaca). J. Chem. Eng.Bioanal. Chem. 2017, 2, 49-61. [CrossRef]

33. Afolabi, I.S. Moisture Migration and Bulk Nutrients Interaction in a Drying Food Systems: A Review. Food Nutr. Sci. 2014, 5, 692-714. [CrossRef]

34. AOAC. Official Methods of Analysis of AOAC International, 19th ed.; AOAC International: Gaithersburg, MD, USA, 2012.

35. Singleton, V.L.; Orthofer, R.; Lamuela-Raventos, R.M. Analysis of total phenols and other oxydant substrates and antioxydants by means of Folin-ciocalteu reagent. Methods Enzymol. 1999, 299, 152-178.

36. Meda, A.; Laien, C.E.; Romito, M.; Millogo, J.; Nacoulma, O.G. Determination of total phenolic, flavonoid and proline contents in Burkina Faso honeys as well as well as their radical scavenging activity. Food Chem. 2005, 91, 571-577. [CrossRef]

37. Latta, M.; Eskin, M. A simple and rapid colorimetric method for phytate determination. J. Agric. Food Chem. 1980, 28, 1313-1315. [CrossRef]

38. Day, R.; Underwood, A. Quantitative Analysis, 5th ed.; Prentice-Hall Publication: Upper Saddle River, NJ, USA, 1986.

39. Price, M.L.; Van Scoyoc, S.; Butler, L.G. A critical evaluation of the vanillin reaction as an assay for tannin in sorghum grain. J. Agric. Food Chem. 1978, 26, 1214-1218. [CrossRef]

40. Obadoni, B.O.; Ochuko, P.O. Phytochemical studies and comparative efficacy of the crude extracts of some homeostatic plants in Edo and Delta States of Nigeria. Glob. J. Pure Appl. Sci. 2001, 86, 203-208.

41. Amarteifio, J.O.; Mosase, M.O. The Chemical Composition of Selected Indigenous Fruits of Botswana. J. Appl. Sci. Environ. Manage. 2006, 10, 43-47. [CrossRef]

42. Murray, S.; Schoeninger, M.J.; Bunn, H.T.; Pickering, T.R.; Marlett, J.A. Nutritional composition of some wild plant foods and honey used by Hadza foragers of Tanzania. J. Food Compos. Anal. 2001, 14, 3-13. [CrossRef]

43. Otten, J.J.; Hellwig, J.P.; Meyers, L.D. Dietary Reference Intakes: The Essential Guide to Nutrient Requirements; Institute of Medicine: Washington, DC, USA, 2006.

44. Mateke, S.M. Botswana's Indigenous Fruit Tree Domestication and Improvement Project 1997-2001, Final Report. 2001.

45. Theobald, H.E. Dietary calcium and health. Nutr. Bulletin. 2005, 30, 237-277. [CrossRef]

46. Palmer, B.F. Regulation of potassium homeostasis. Clin. J. Am. Soc. Nephrol. 2015, 10, 1050-1060. [CrossRef]

47. Ringer, J.; Bartlett, Y. The significance of potassium. Pharm. J. 2007, 278, 497-500.

48. Appel, L.J. Nonpharmacologic therapies that reduce blood pressure: A fresh perspective. Clin. Cardiol. 1999, 22, 1111-1115. [CrossRef]

49. Jasar, D.; Kubelka-sabit, K.; Trajkovska, B.C.; Filipovski, V. Vitamin B3 dietary intake and its role in aging. J. Hyg. Eng. Des. 2015, 13, 90-93.

50. Pullar, J.M.; Carr, C.; Vissers, M.C. The roles of vitamin C in skin health. Nutrients. 2017, 9, 866. [CrossRef]

51. Dave, K.N.; Patil, R.S. Biological importance of ascorbic acid (vitamin C) in human health-A classic review. Int. J. Res. Biol. Pharm. 2017, 3, 1-8.

52. Aslam, M.F.; Majeed, S.; Aslam, S.; Irfan, J.A. Vitamins: Key role players in boosting up immune response-A mini review. Vitam. Miner. 2017, 6, 153. [CrossRef]

53. Fiedor, J.; Burda, K. Potential role of carotenoids as antioxidants in human health and disease. Nutrients 2014, 6, 466-488. [CrossRef]

54. Ozcan, T.; Akpinar-Bayizit, A.; Yilmaz-Ersan, L.; Delikanli, B. Phenolics in human health. Int. J. Chem. Eng. Appl. 2014, 5, 393-396. [CrossRef]

55. Tiwari, S.C.; Husain, N. Biological activities and role of flavonoids in human health-A review. Indian J. Sci. Res. 2017, 12, 193-196.

56. Thompson, L.U. Potential health benefits and problems associated with antinutrients in foods. Food Res. Int. 1993, 26, 131-149. [CrossRef]

57. Nititham, S.; Komindr, S.; Nichachotsalid, A. Phytate and fiber content in Thailand fruits commonly consumed by diabetic patients. J. Med. Assoc. Thai. 2004, 87, 1444-1446.

58. Muhammed, I.; Muh, S.; Olorunju, S.; Bale, J.; Abdullahi, U.; Lawal, R. Response of nutrients and anti-nutritional constituents in the seeds of Cassia tora L. to treatments. J. Agric. Environ. 2002, 3, 225-234. 
59. Faizal, A.; Geelen, D. Saponins and their role in biological processes in plants. Phytochem. Rev. 2013, 12, 877-893. [CrossRef]

60. Bora, P. Anti-nutritional factors in foods and their effects. J. Academ. Indust Res. 2014, 3, 285-290.

61. Garcia-Casal, M.N. Carotenoids increase iron absorption from cereal-based food in the human. Nutr. Res. 2006, 26, 340-344. [CrossRef] 